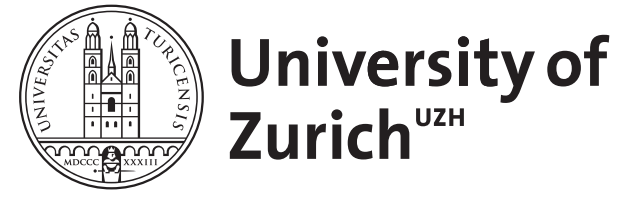
Archive

University of Zurich

University Library

Strickhofstrasse 39

CH-8057 Zurich

www.zora.uzh.ch

Year: 2006

The Global, the Local, and the Parochial

Biller-Andorno, Nikola

DOI: https://doi.org/10.1007/s00481-006-0470-6

Posted at the Zurich Open Repository and Archive, University of Zurich

ZORA URL: https://doi.org/10.5167/uzh-155791

Journal Article

Published Version

Originally published at:

Biller-Andorno, Nikola (2006). The Global, the Local, and the Parochial. Ethik in der Medizin, 18(4):390392.

DOI: https://doi.org/10.1007/s00481-006-0470-6 
Ethik Med 2006 · 18:390-392 DOI 10.1007/s00481-006-0470-6 ○) Springer Medizin Verlag GmbH 2006

Nikola Biller-Andorno $\cdot$ Zürich

\title{
The Global, the Local, and the Parochial
}

\author{
A commentary on Vilhjálmur Árnason
}

etermining what general rules mean in specific situations and how global principles and local context relate to each other are important issues in medical ethics that have become the subject of an increasingly lively international debate $[2,4,7,9,10]$. I agree with Árnason [1] that simple answers - be they "it's all in the principles" or "it's all in the context" - do not work. And I agree that we will have to live with the creative tension that is being brought about by the dual strife for enlightenment by global principles and sensitivity to local context.

However, the fruitful exchange about the role of the global and the local is put at risk not only by the "rigid principlism" and "narrow contextualism" that Árnason describes, but also by a third danger, for which I would like to suggest the term "bioethical parochialism".

\section{Bioethical parochialism}

What do I mean by my concern that the tension between the global and the local may collapse in the parochial? "Parochial" has a double meaning: 1 . pertaining or restricted to a parish, and 2. limited, characterized by narrow interests centered on oneself or one's local community, narrow-minded, provincial [5].

The first aspect could be reasonably integrated into the global - vs. - local debate: Are there moral arguments that are particularly relevant or even limited to a certain - local, religious, political or otherwise defined community? A classic example is the rejec- tion of blood transfusions by Jehova's witnesses, but there are many arguments in bioethics that would merit a closer look regarding their "parochial" nature. What is the legitimate role of such arguments in the global discourse on bioethical matters; should they weigh in, be simply tolerated or rejected if they are obviously bound to a belief system or other particular perspectives? What are the obligations of professional ethicists who are also members of communities with strong moral commitments; how can they manage to adhere to academic standards without compromising their loyalty to the community they belong to? "Parochial" concerns, values, arguments, in fact, form part of specific local contexts, and their articulation and reflection can indeed advance our understanding of bioethics discourses, their way of functioning as well as their limits.

The second notion - parochialism as characterized by a narrow focus on the interests of one's own community and a disregard for the moral questions (or answers) put forward by others - is more difficult to integrate into a genuine, open exchange on moral matters. It is this form of parochialism which I see as a threat to a fruitful debate and which I will turn to now. Moral parochialism in this sense brings with it a more or less predefined list of moral issues considered worthy of discussion, with fixed priorities that distinguish between the "real" issues and those that have been judged to be secondary. In a similar way what counts as "profound", "superficial" and "misguided" arguments may be defined even before a meaningful exchange has taken 
place. When the moral parochialists enter the scene, moral positions become interests that have to be defended, and philosophers turn into politicians; creativity gets limited to its strategic dimension of how to best sell an argument or force it upon others; open questions and moral curiosity start being considered ignorance and naïveté. This danger may be the price of pluralism with its ambition to find ways to exchange views about different positions on moral matters and to maybe even reach sensible - if not rational - solutions. Recognizing this danger and making it explicit may help contain it, possibly through the formulation of suitable rules for bioethics discourses.

Bioethical parochialism can take different forms. To begin with, direct parochialism can be distinguished from indirect parochialism. Direct parochialism advocates for its agenda by invoking the local context, thus arguing for exceptions to generally recognized principles or for a particular interpretation of these principles. This argumentative strategy is, for example, used to defend female circumcision, which - at least prima facie - departs from the principles of nonmaleficence, beneficence, and in most cases of autonomy; local factors, so the parochial argument, turn what seems to be a violation of physical and psychological integrity into a beneficent act by ensuring the girl and future woman a regular place in the social structure in which she is embedded.

Indirect parochialism, on the other hand, claims to be concerned about global principles whereas in fact it aims to foster its own particular goals. Human dignity is a globally recognized concept that lends itself to be used as a foil for very different parochial agendas. For example, it is invoked by the proponents as well as the opponents of active euthanasia. It has also been quite impressive to observe how particular agendas were fought for under the umbrella of global principles when the possibility of a convention on human cloning was debated in the United $\mathrm{Na}$ tions [3].

Parochialism can be either explicit or implicit, i.e. working with open or hidden agendas, and it can be employed in an unaware or in a very conscious, reflected manner. It is the indirect, implicit, conscious form of parochialism that should concern us most when it enters bioethical discourse; particularly so as many bioethical issues touch on dearly held beliefs or convictions which provide the motivation for fierce fights. Ethics done from such a parochial perspective does not adhere to the usual standards of open, respectful intellectual exchange. It will use the tension between the global and the local for its own purposes - bioethical discourse will either be instrumentalized or turned into an irrelevant puppet show, with the "real action" going on behind the scenes.

\section{Parochialism and anti-bioethics}

Parochialism is a global phenomenon. Is the bioethics discourse in Germany more at risk than in other places? There are several local features that could be discussed as providing a fertile soil for an instrumentalization of biomedical ${ }^{1}$ ethics debates for parochial purposes.

One of these features is a certain form of "anti-principalism". This does not address the anthropological contextualist critique of principalism that Árnason describes in his paper [1], which anyway has been more pronounced in North America than in Europe. Nor does this problematic form of "anti-principalism" refer to replies from "continental philosophy", among them Kantian, hermeneutical or phenomenological approaches. Rather, what is meant is a vague but strong discomfort with mid-level principles as being too soft, too amenable to negotiation and compromise, too void of "real" values. Once you start weighing and balancing mid-level principles, so the concern, you are already halfway down the slippery slope. ${ }^{2}$ The pro-

\footnotetext{
1 "Biomedical" is understood here as comprising bio - as well as medical ethics.

2 The suspicion is thus not so much directed against the principles as such but against their mid-level nature and the inductive element the approach contains. The case law approach that gives considerable weight to contextual details provokes similar concerns.
} 
posed alternative consists in reassuring ourselves of traditional or supposedly universal values. This re-orientation towards the wellknown, secure might be an expression of a society in crisis [6] that does not have confidence in its ability to approach bioethical questions through open, fair, participatory discourses that could do justice to the pluralist nature of contemporary societies but views such an approach as naïve or dangerous.

Another feature is a moralizing and in part aggressive anti-utilitarianism that polarizes between utilitarians that supposedly limit their moral argumentation to accruing benefits, ephemeral as they may be, and those "serious" ethicists that judge moral actions by concentrating on the "real" values that are at stake. In this perception utilitarians would, for example, allow handicapped newborns to be killed in order to remove cumbersome obstacles to the pursuit of happiness, whereas serious ethicists would not be so easily distracted from core values like the sanctity of human life. Framed this way it is clear from the outset who the "good guys" and who the "bad guys" are, without a further exploration of the complexities of the argumentation in question. Accordingly, intellectual exchange is replaced by defamation or even overt hostilities [8]. This kind of anti-utilitarianism fits well with a general "anti-bioethics" attitude, which suspects that "bioethicists" are in fact just servants to the biotechnological industry.

This fundamental disrespect for a genuine and open exchange on bio- and medico-ethical matters can serve as legitimation for undermining bioethical discourse through parochialist strategies. Those who already know that "they" are the "good people" defending the "real values" may see it as perfectly justifiable to instrumentalize bioethics for advancing their own - morally right - agenda. In Germany this move is sometimes given more weight by a feeling of special responsibility for historical reasons to counter any possible erosion of moral standards.

It would be fatal for medical ethics as an academic discipline if the parochial succeeded in suffocating bioethical discourse. Those critics would then be right who see bioethics as nothing else than window-dressing or a stage for political power fights. To help prevent such a sorry state and to foster the development of medical ethics by providing an appropriate forum for exchange and debate may well be the most important task of the Academy for Ethics in Medicine in the twenty years to come.

\section{Anschrift}

\section{Prof. Dr. Dr. Nikola Biller-Andorno}

Lehrstuhl für Biomedizinische Ethik

Ethik-Zentrum der Universität Zürich

Zollikerstr. 115

8008 Zürich, Schweiz

E-Mail: biller-andormo@ethik.unizh.de

\section{Literatur}

1. Árnason V (2006) The Global and the Local: Fruitful Tensions in Medical Ethics. Ethik Med 18

2. Biller-Andorno N (2001) Gerechtigkeit und Fürsorge. Zur Möglichkeit einer integrativen Medizinethik. Campus, Frankfurt a.M. New York

3. Biller-Andorno N (2006) Cross-Cultural Discourse in Bioethics: It's a Small World After All? In: Roetz H (ed) CrossCultural Issues in Bioethics. The Example of Human Cloning. Rodopi, Amsterdam, pp 459-463

4. Eich T, Hoffmann TS (Hrsg) (2006) Kulturübergreifende Bioethik. Zwischen globaler Herausforderung und regionaler Perspektive. Karl Alber, Freiburg München

5. http://www.webster-dictionary.net/definition/Parochial; accessed on September 29, 2006

6. Krones T (2006) The scope of the recent bioethics debate in Germany: Kant, crisis, and no confidence in society. Camb Q Healthc Ethics 15(3):273-281

7. Macklin R (1999) Against Relativism: Cultural Diversity and the Search for Ethical Universals in Medicine. Oxford University Press, Oxford New York

8. Schöne-Seifert B, Rippe KP (1991) Silencing the Singer. Antibioethics in Germany. Hastings Center Report 21(6):20-27

9. Schulz-Baldes A, Jakovljevic A (2006) Zur Möglichkeit einer kulturübergreifenden Bioethik. Interdisziplinärer Workshop des Lehrstuhls für Biomedizinische Ethik und der Arbeitsund Forschungsstelle für Ethik (Universität Zürich) in Kooperation mit der Jungen Akademie der Berlin-Brandenburgischen Akademie der Wissenschaften und der Akademie für Naturforscher Leopoldina. Ethik-Zentrum der Universität Zürich, 30. März bis 1. April 2006. Ethik in der Medizin 18:261-266

10. Tao J (ed) (2002) Cross-cultural Perspectives on the (Im)Possibility of Global Bioethics. Kluwer, Dordrecht Boston London 